Bull. Geol. Soc. Finland 41, 3-20 (1969)

\title{
THE NORTHERN DISCHARGE CHANNEL OF ANCIENT PÄIJÄNNE AND THE PALAEOHYDROLOGY OF THE ATLANTIC PERIOD
}

\author{
RISTO AARIO \\ Department of Geology, University of Oulu \\ Appendix by \\ Viljo CASTRÉN \\ Institute of Technology, Otaniemi
}

\begin{abstract}
The discharge and run-off of the Atlantic period are determined by the morphological measurements in the channel of the ancient Hinkua River discharging from the Finnish Lake Plateau. The climatic interpretation is discussed. The small run-off value and the dryness of the Atlantic period are in the first place a direct consequence of the greater evaporation caused by higher temperature.
\end{abstract}

\section{CONTENTS}

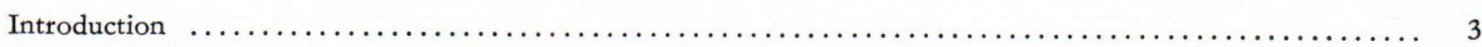

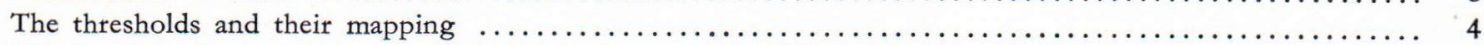

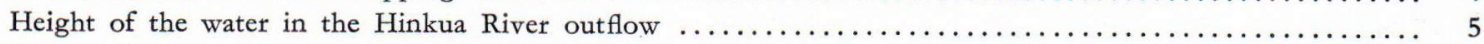

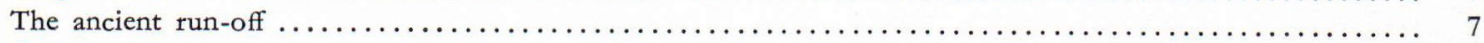

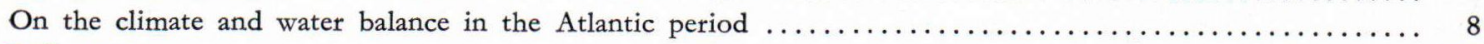

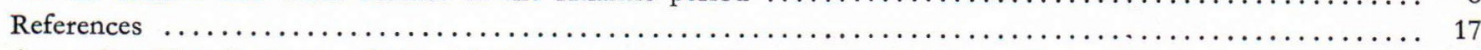

Appendix: The discharge of the old Päijänne channel (By Viljo Castrén) $\ldots \ldots \ldots \ldots \ldots \ldots \ldots \ldots \ldots \ldots \ldots$

\section{Introduction}

Following its isolation from Ancylus Lake, ancient Päijänne initially discharged northwards to the Gulf of Bothnia, through its northern discharge channel, the Hinkua River. The transgression caused by the land-tilting, however, later led to the formation of a new discharge channel on the more slowly rising south- ern part of the basin, at Vuolenkoski (Tolvanen 1922; L. Aario 1936, 1952 a; R. Aario 1965 a, cf. also Ramsay 1926). The old Hinkua River in the north was left dry. Since erosion of the river bed ceased at that time and since subsequent erosion there has been insignificant, the bed of the Hinkua River has remained in the same state up to the present day as it was when the change of the channel took place. A great 
part of the channel has, it is true, been covered by bogs. The morphological and hydrological characteristics of this first bed are consequently determinable with the aid of measurements and drilling. The ancient water level in the channel can also be determined by field studies.

The height of the water level and the width and the form of the channel determine the quantity of water $\left(\mathrm{m}^{3} / \mathrm{s}\right)$ that has flowed in it and clarification of this makes it possible to examine the ancient water budget of the Hinkua River drainage area (R. Aario 1966). The information necessary for the calculation of the amount of water was obtained between 1960-64 by the study of ancient shore lines (R. Aario 1965 a) and in 1965 by mapping the threshold areas at the Hinkua River outflow. Hydraulic calculations were kindly performed by Professor Viljo Castrén, Professor of Hydraulics (p. 18).

\section{The thresholds and their mapping}

The threshold areas of Kotajärvi and Ollove were mapped tachymetrically, the Karhunpiilo area by line measurement, which was supplemented at the narrowest point of the channel by additional values measured tachymetrically (Fig. 1). Measured points represent at each place the general level, and care was taken to avoid both holes and stones rising above their surroundings. The position of the surface of the peat covered hard base was determined with a steel rod. Height values are based on the fixed bench marks of the railway track traversing the area.

At both the Ollove and Kotajärvi thresholds (= Tolvanen threshold) there is an islet at the mid-point of the channel which has divided the flow (Plates I-II). The deepest part of the channel upwards and downwards from the Ollove threshold is in the north-west. Since, however, the threshold itself is high at this point, the majority of the water mass has had to pass around the eastern side of the islet. At the Kotajärvi threshold the islet itself obstructs the deepest channel and the flow is distributed

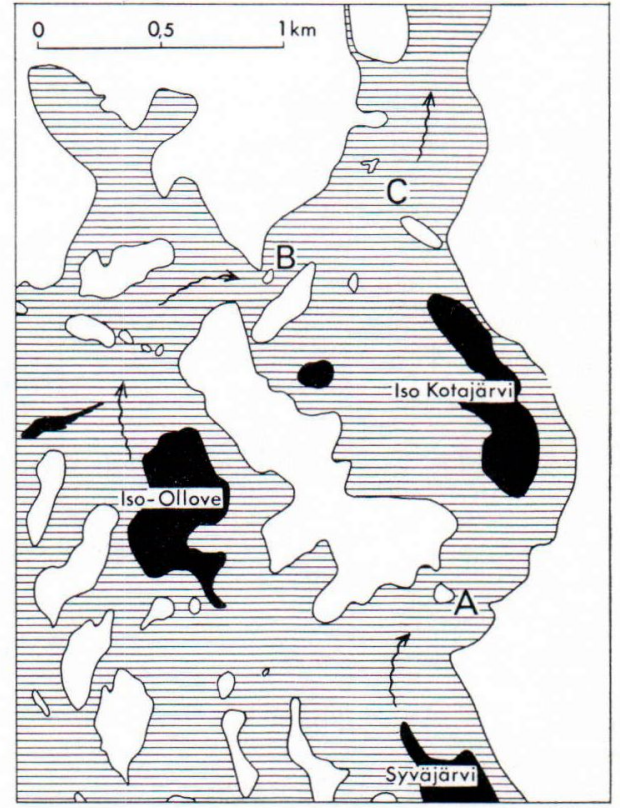

FIG. 1. Northern threshold area of ancient Lake Päijänne. The shaded area was under water when the ancient Hinkua River was flowing. Discharge indicated by arrows. $\mathrm{A}=$ Kotajärvi threshold, $\mathrm{B}=$ Ollove threshold, $\mathrm{C}=$ Karhunpiilo threshold.

more evenly on both sides of the islet than in the previous case. At both thresholds the channel deepens and widens immediately below the thresholds so that the descent is restricted to a short distance and is followed by a quiet stretch of water. The height of the water here is regulated by narrows at Karhunpiilo (Plate III).

At the Karhunpiilo narrows also there is a higher point in the centre parts but only a negligible portion of this has extended up to the surface. The portion of the channel on the western side of this is shallow and soon after crossing the threshold bends sharply towards the east to join the main channel. The main channel is relatively straight and the gradient of the base below the threshold is regular. Further to the east there is yet another narrow channel, the threshold height of which is $122.6 \mathrm{~m}$. The washed part of this, however, extends to only a little above the threshold and since the channel 
width is also small it has no practical significance in evaluating the discharge of the Hinkua River.

In the mapped region the Hinkua River is on a till-covered foundation (R. Aario 1965 a, pp. 60-67), where the bed is rough and there are numerous islets hindering the flow. The form of the channel is therefore disadvantageous to flow, so that the volume of water discharging per square unit of the cross-section remains smaller than in morphologically well developed river channels.

\section{Height of the water in the Hinkua River outflow}

The height of the water level of ancient Lake Päijänne employed for calculations was determined in the customary manner with the aid of shore formations. Since the discharge is largely dependent on the water height, these determinations may, however, require closer inspection.

During a certain shore stage morphological shore lines are formed depending on local conditions at different levels corresponding to various annual heights of water. Thus, on the shores of Päijänne and Saimaa, for instance, $2-3$ different shore formations of varying levels can at present be observed in many places. From these formations the bases of the strongest and most continuous erosion scarps and rims of icepushed boulders are created, according to several researchers, approximately at the mean high water level (Hellaakoski 1928, p. 8; Nussbaum 1934, p. 323; King 1959, pp. 228-230; Varjo 1964). According to extensive research by the National Board of Public Roads and Waterways the base of the shore scarp at Lake Oulujärvi was on the average even above this (V. Castrén, advised orally). Generally the bases of erosion scarps bordering on the open sea form at a higher level than on protected shores.

After the water has descended from the levels in question frequently only the above mentioned strongest morphological shore marks remain in the terrain as distinctly noticeable formations. For this reason the height determinations of ancient shore stages, whose readings are measured from the bases of erosion scarps and boulder rims, correspond generally to mean high level or slightly above.

However, shore marks, generally weakly developed, representing other annual water levels may sometimes in local conditions remain as permanent features after the water has permanently fallen while, for instance, the shore marks of mean high water deteriorate or even disappear. For this reason special caution must be exercised so that by measurements of a certain shore stage the corresponding (seasonal) water level can actually be found everywhere. Similarly efforts must be made to distinguish the random and generally local shore formations created during short-term shore stages from those formed during long-term stages (i.a. Varjo 1964). By following the continuity of individual shore formations and performing numerous observations of shore morphology in different situations both the above - mentioned misleading factors can generally be avoided.

In the northern parts of ancient Päijänne the first of the investigations concerning ancient shorelines was carried out by Viljo Tolvanen (1922). He obtained a figure of about $123 \mathrm{~m}$ for the height of ancient Päijänne at the outflow of the Hinkua River. Ramsay (1926) arrived at the same value on the basis of the few observations he performed in the area.

The author's shoreline investigations in the vicinity of the northern discharge channel were carried out in the summers 1960-1964 (R. Aario 1965 a, pp. 126-131). The shoreline of ancient Päijänne was followed at that time for about $30 \mathrm{~km}$ from the center of Pihtipudas up to the Hinkua River outflow.

In the vicinity of the thresholds several shore observations were somewhat under $123 \mathrm{~m}$ and only a few, generally a little doubtful, slightly above the figure (R. Aario 1965 a, p. 127). 


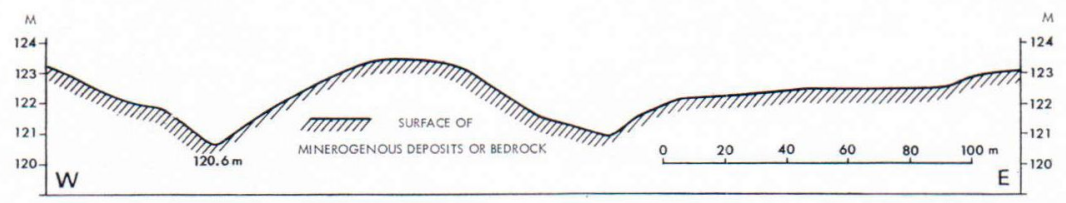

Frg. 2. Kotajärvi threshold profile.

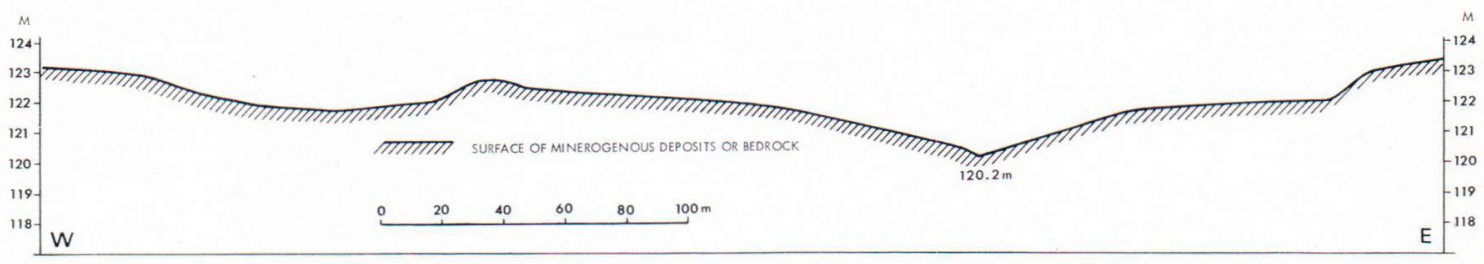

FIG. 3. Karhunpiilo threshold profile.

Formations suggestive of ancient shores do not appear above the 123 metre height, at least not notably to any more general extent than on any other levels, so that these must be included among the random shore formations mentioned. According to these observations the morphological shoreline corresponding to ancient Päijänne's mean high water level has been slightly under $123 \mathrm{~m}$, that is to say close to the $123 \mathrm{~m}$ that Tolvanen and Ramsay arrived at. Since the levelled values are on an average a little below this figure and the shore scarp base often forms slightly above the (mean high) water level it represents, this height value is to be regarded as the maximum.

In the channel narrows the former height of the water was determined on the basis of the analyses of the bottom and the shore slopes. The stony bed, where stones are raised up from their foundation and in many places even loose, is below $123 \mathrm{~m}$ at all three areas of investigation. Above this limit the appearance of stones on the surface is less and usually only the tops of the boulders rise somewhat out of their foundation. At Karhunpiilo where the soil is free from plant growth on a well worn trail the limit is at the height of $122.6-122.7$ metres and distinctly ascertainable. Above this limit all the stones except the larger boulders are almost entirely submerged in loose sand, which in the bed of a rapids would have been quickly washed away.

The cross profile of the bed also gives the same height for the water level in the Hinkua River outflow. As has been mentioned previously (R. Aario 1965 a, pp. 60-67), the Hinkua River on a stony till foundation was not capable of creating as distinct a river bed as the large rivers of recent times on the south coast. In parts of the narrows such as at the thresholds of Kotajärvi, Ollove and Karhunpiilo, however, the vigorous flow of water has deepened the river bed. At the thresholds of Kotajärvi and Karhunpiilo, especially, (Figs. 2 and 3) the valley slopes become distinctly more gentle above the level of about $122.5-123 \mathrm{~m}$. The upper slope is the original, whereas the steepening lower down is caused by the erosion of running water. This shows the water level to have been below the height of $122.5-123 \mathrm{~m}$.

In calculating the capacity of the channel the above-mentioned round maximum value of $123 \mathrm{~m}$ has been used for the whole threshold area. The tilting of the land in fact provides a basis for calculating that the Ollove threshold has risen $10-15 \mathrm{~cm}$ more than the Kotajärvi threshold. This difference, however, cannot be ascertained by studies of shore formations. Due 
to the narrow straits above the Ollove threshold the water level at this outflow has probably been slightly lower than at the outflow at the Kotajärvi threshold, and therefore the present heights of the ancient water levels would in fact be approximately the same. The Karhunpiilo narrows lie on the same isobase as the Ollove threshold and so no differences have arisen for the height values of the water level due to land-tilting.

\section{The ancient run-off}

The Hinkua River drainage basin ${ }^{1}$ ) consisted of the present drainage areas of Saimaa (the Vuoksi River discharge area) and Puulavesi in addition to the present Päijänne area (the Kymijoki River discharge area) or a total of about $92800 \mathrm{~km}^{2}$ (Fig. 4). The mean discharge of the Kymijoki River at Mankala is $225 \mathrm{~m}^{3} / \mathrm{s}$ and the corresponding drainage area $28605 \mathrm{~km}^{2}$ (Saarinen 1966, p. 13). The mean discharge of Vuoksi at Imatra is $553 \mathrm{~m}^{3} / \mathrm{s}$ and the corresponding area $61275 \mathrm{~km}^{2}$ (Ibid., p. 11). Information I have received from the Hydrological Office states that the mean discharge of the Puula water system is $31 \mathrm{~m}^{3} / \mathrm{s}$ at Kissakoski and its

1) After having been isolated from the Baltic, Puulavesi discharged into Päijänne until the 1800 's when a way to the watercourse was opened by the present discharge channel to the Mäntyharju water system (Hellaakoski 1928).

Saimaa, following its isolation, initially discharged from its north-west part into Päijänne (Hellaakoski 1922, 1936; Sauramo 1940, 1958; Okko 1948, 1965; Lappalainen 1962). From here, according to Okko (1965), the discharge channel moved southwards at about 5500 B. P., apparently to the isthmus between Sorsavesi and Iisvesi at Suonenjoki. The lake still continued to discharge into Päijänne, however. Only in association with later changes in the discharge channel was the Päijänne connection blocked.

As the change in the discharge channel of ancient Päijänne from the Hinkua River to the present-day Kymijoki took place already at about 5800 B. P. (R. Aario $1965 \mathrm{a}, \mathrm{b})$, then according to the above-stated facts the Hinkua River, during the whole period of its activity, has been the common discharge channel for Päijänne, Saimaa and Puulavesi. Even the next discharge channel of the Päijänne watercourse, the present-day Kymijoki River, at first functioned for some time as the common discharge channel of these three watercourses.

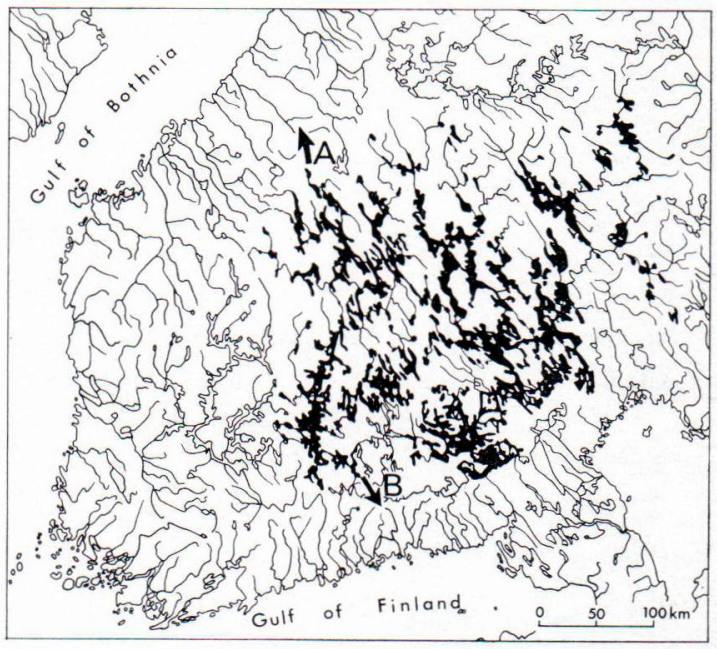

FIG. 4. Present lakes and rivers in the Hinkua River discharge area. $\mathrm{A}=$ The Hinkua River, $\mathrm{B}=$ The Kymijoki River.

area $3460 \mathrm{~km}^{2}$. Together these drainage areas total approximately $93300 \mathrm{~km}^{2}$ and the discharge $809 \mathrm{~m}^{3} / \mathrm{s}$, which corresponds to a mean run-off of about $8.8 \mathrm{1} / \mathrm{s} . \mathrm{km}^{2}$. The sum total for the drainage areas should be the same as the drainage basin of the Hinkua River. The negligible difference comes about because the present discharge for the Kymijoki River has been taken at Mankala and not at Vuolenkoski and, as regards the Puula drainage area, at Kissakoski and not at the Puula outflow, since more reliable series of observations have been available for the first mentioned. The difference, however, is meaningless from the standpoint of calculating mean run-off. The run-off corresponding to mean high water is 11.4 1/s. $\mathrm{km}^{2}$ for the Vuoksi drainage area and $11.5 \mathrm{l} / \mathrm{s} . \mathrm{km}^{2}$ in the Kymijoki River area.

With the former height of water level at the threshold being at the present height of $123 \mathrm{~m}$, Professor Castrén has calculated the Hinkua River discharge to be $630-650 \mathrm{~m}^{3} / \mathrm{s}$ (p. 18). The corresponding run-off is about $7 \mathrm{l} / \mathrm{s} . \mathrm{km}^{2}$ concerning the run-off at mean high water. If the ratio $\mathrm{Mq} / \mathrm{MHq}$ in the Hinkua River 
drainage basin had been the same as nowadays in the same area, the figure for the mean run-off of the Hinkua River would be $5.3 \mathrm{l} / \mathrm{s} . \mathrm{km}^{2}$, which is only about $60 \%$ of the present figure. When estimating the mean run-off for the Hinkua River, however, two contradictory factors must be taken into account. In large water systems the difference $\mathrm{MHq}-\mathrm{Mq}$ is smaller, because water masses from different distances meet the discharge channel at different times, so that the high water stage is distributed over a longer period. On the other hand, the location of the discharge channel in the north accentuates the flood, because in the south, in the upper reaches of the watercourse, the melting of the snow occurs earlier. Of these factors the former has the greater effect as the thaw progresses towards the north faster than the flow of waters from the upper areas to the discharge channel after snow melting. The mean run-off is therefore greater than $5.31 / \mathrm{s} . \mathrm{km}^{2}$. The rounded-off value of $6 \mathrm{l} / \mathrm{s} . \mathrm{km}^{2}$ is probably relatively close to the correct figure. This is $70 \%$ of the present value.

When judging the reliability of the result it must be affirmed that the factors pertaining to the channel's morphology, such as the crosssection as well as the roughness and declivity of the bed, have been determined in the terrain exactly by levelling. No significant inaccuracy has therefore been able to result from measurement to affect hydraulic calculations.

The morphological method employed for determining ancient water heights is, however, less precise (i.a. R. Aario 1965 a, p. 8). The value of water height used in the calculations is the maximum value. In reality the discharge may be even considerably less than that derived from calculations and correspondingly the difference from the present even greater.

The discharge corresponding to the present mean water would be reached with the water being some $35 \mathrm{~cm}$ higher than the maximum value of $\mathrm{MHq}$ in my determination (p. 18). This value would imply, however, an incipient rise of water over the banks of the ancient bed.

As the ancient drainage basin to be examined is accurately known (p. 7), the difference in the run-off value compared with the present cannot arise from differences in the surface areas of the former and the present drainage areas.

Nor can it be assumed that the changes in the flow of underground water resulting from landtilting could substantially change the discharge quantities. The till deposit on an uneven crystalline bedrock is relatively thin and nearly impervious to water. In addition the Lake area in question in its entirety is a basin, restricted by higher peripheral areas, from which the flow of underground water is not directed towards the sea coast, except to some small extent in the border areas. Changes in the discharge quantities must therefore arise from climatic changes.

\section{On the climate and water balance in the Atlantic period}

The run-off values presented, $\mathrm{Mq}=6 \mathrm{l} / \mathrm{s} . \mathrm{km}^{2}$ and $\mathrm{MHq}=7 \mathrm{l} / \mathrm{s} . \mathrm{km}^{2}$ correspond to the situation in the Lake area before the change of the discharge channel about 5800 B. P. (R. Aario $1965 \mathrm{a}$ and b). The isolation time of Päijänne has not been determined as precisely. The isolation took place about 2000 years before the change of the discharge channel and clearly later than the time at which alder became common (R. Aario 1965 a, pp. 58-59). During all the northern discharge phase of the Päijänne water system the amount of alder, hazel, elm, lind and oak was greater than at present. As regards climatic history this phase corresponds to the middle and closing stage of the so-called Atlantic period (i.a. Sauramo 1958, p. 44). According to the climate schema of Blytt and Sernander, which in this regard still corresponds to the concept prevailing in Finland, the period would have been warm and humid.

It has been possible to ascertain that temperature fluctuations are commonly simultaneous and 
of the same direction over extensive areas, and undoubtedly the Atlantic period here was also warmer than at present. Fluctuations in humidity are dependent, however, on very many different factors, and thus the changes don't take place in the same way everywhere. There have been, in fact, conflicting opinions presented on the humidity of this period as predicted by Blytt-Sernander's schema of climate.

L. Aario has come to the conclusion on the basis of the intensity of bog formation that the Atlantic period was, at least in Petsamo in Arctic Sea coast, dry from the beginning of the Tapes period (1943, p. 87). As regards south Finland he has considered this period to be approximately as humid as the present climate or possibly slightly drier, because at that time domed raised bogs were very few in number (1944, pp. 44-45).

Aartolahti (1966) has also touched on this question as regards Finland. According to him Lapland appears to have been dry on the closing stage of the Atlantic period during the spread of the spruce.

In south Sweden, according to Granlund (1932), raised bogs require an annual rainfall of at least $460 \mathrm{~mm}$ in order to become convex and as rainfall increases this convexity becomes more pronounced. Based on the convexity of bogs at different periods as well as on the occurrence of recurrence surfaces and the intensity of bog formation, he has further drawn conclusions bearing on fluctuations of climatic humidity conditions compared with both adjacent periods and the present. In the main, Granlund's investigations cover the younger stages than the Atlantic period, but on the base of this material he has concluded, that the Atlantic period was drier than the present. However, determination of convexity characteristic of a certain period with the aid of bog stratigraphy is not easy. Since the convexity of raised bogs generally becomes more pronounced with age and does not always manage to attain the maximum value char- acteristic of the humidity during each period, the later periods seem to be more humid than the earlier. By constructing the positions of a bog surface during certain periods with pollen diagrams the convexity of the ancient bog surface may often be underestimated to, since the older layers have to some extent become compressed under the weight of the more recent strata. This is especially true in the central parts of the bog where the peat is at its thickest. Without special studies the degree of consolidation is difficult to estimate with accuracy so that the ancient convexity could be determined with certainty. Also the interpretation of recurrence surfaces has later proved to be more complicated than was presumed earlier, after it has been shown (e.g. Averdieck 1957, Lundqvist 1962 , p. 8) that even the same recurrence surface can be of a different age in different parts. In spite of the difficulties attaching to Granlund's method of investigation and the paucity of research material concerning this period, the result seems logical and is not in contradiction with my own investigations.

In the examination of the humidity of the Atlantic period generally no comparison has been made, however, with the present, but rather with adjacent periods and, in particular, the Atlantic period is considered to be more humid than the Boreal period, with the exception though of the northernmost parts of our country (L. Aario 1943, pp. 108-110). Also as regards the Boreal period thought could be given to arriving at more absolute average values for the Baltic Sea by clarifying the discharge values of the Svea River, provided the hydraulic characteristics of the channel and the height of the water level at the outflow of that time are still determinable.

The Atlantic period was apparently not wholly of a uniform nature, rather it exhibited more humid phases and drier phases (i.a. Jørgensen 1963; T. Nilsson 1964 a, b; cf. also Berglund 1966). The latter phase of the period has been considered drier than the initial phase. 
So, according to Nilsson's investigations of the Agerödsmosse bog the initial phase of the Atlantic period (6 200 B. C. -4600 B. C.) was humid while the final phase (4600 B. C.3300 B. C.) was drier.

Based on this the humid period would perhaps even have ranged to the first part of Päijänne's northern discharge stage. Some weak shore formations above the $123 \mathrm{~m}$ level could perhaps be considered as actually revealing such a humid phase in the Päijänne district, too. That part of the humid phase of the Atlantic period which would extend to the time of the northern discharge would, nevertheless, have been of relatively brief duration, since the shore formations are meagre and because the established erosion bed clearly corresponds to the shore level running below the $123 \mathrm{~m}$ level. Also, the washing has been weak above this limit (p. 6).

In Germany Granlund's opinion that the Atlantic period would have been rather dry has met criticism i.a. by Gross (1933), who regards this period as humid. This seems to be supported by the fact that Sphagnum papilıosum and Sph. imbricatum, both in Germany clearly Atlantic species with a sharp SE limit a bit eastward from Bremen, have been found in the older Sphagnum peat corresponding to the Atlantic period in two raised bogs in the vicinity of Lüneburg, thus far outside their present distribution area (Overbeck and Schneider 1938; Borgässer 1941). On the other side, in the narrow coastal belt where these two species now dominate on raised bogs, they are according to the bog profiles of Overbeck and Schneider (1940) really dominant in the younger Sphagnum peat but missing in the older. It depends mostly on the strong humification of the peat that makes the species impossible to identify, but even in the layers, where the species have been determined (Ibid. p. 363-364) Sph. imbricatum has been found only in one sample. As an answer to my inquiry Prof. Overbeck has kindly informed me that the humidity of the Atlantic period has been verified only in relation to the adjacent stages, but not in relation to the present time. $\mathrm{He}$ emphasizes that in the Atlantic period shortterm phases of different humidity did appear.

In any case the climate in the Finnish Lake Plateau has clearly been drier than at present during the activity of the Hinkua River. In the following I attempt to examine to what extent this dryness is coordinated with other climatic factors.

In the water budget equation $\mathrm{Q}=\mathrm{P}-\mathrm{E}-$ $\triangle \mathrm{W}$, where $\mathrm{Q}$ represents the water mass discharged from the area, $\mathrm{P}$ precipitation, E evapotranspiration and $\triangle \mathrm{W}$ the increase in the water storage of the area within the interval in question. Since long periods are involved, $\triangle \mathrm{W}$ can be disregarded.

The amount of evapotranspiration depends not only on atmospheric factors but also on the proportion of the land and water areas as well as on the quality of the soil and vegetation. The soil can, in this case, be disregarded because the comparison, in broad outlines, concerns the same area. The variation in the proportion of the land and water areas has been insignificant. In vegetation the share of forests has been slightly greater during the Litorina phase, the amount of bogs smaller and fields lacking, but even in these cases the differences have been small and without decisive significance.

Of the atmospheric factors affecting evapotranspiration changes in temperature could, under our conditions, be regarded as the most important. According to a well-established concept, the temperature was clearly warmer in the Litorina period, which corresponds to the middle and final stages of the Atlantic period, than it is at present. Among others, Andersson (1902), L. Aario (1943) and Iversen (1944) have estimated the temperature as being about $1 \frac{1}{2}-2$ degrees higher than now (See also Lamb 1966 , p. 168). On the north boundary of the Hinkua River drainage basin the annual average temperature nowadays is +2 degrees and on the southern boundary +4 degrees (Kolkki 1960, p. 5, map 1). 
According to the Atlas of Finland (Sirén 1960, map 4) evaporation on the north boundary of the ancient drainage area of the Hinkua River is about $220 \mathrm{~mm}$ and on its southern boundary about $350 \mathrm{~mm}$. The difference is thus about $130 \mathrm{~mm}$. Approximately the same result is arrived at on the basis of evaporation observations for the main drainage areas of Finland presented by Simojoki (1966, p. 19). Assuming that even the previous increase of some 2 degrees in the Atlantic period has brought about an increase in annual evaporation of approximately $130 \mathrm{~mm}$ and taking into account that the mean discharge in millimetres in the Vuoksi watercourse is 285 and in the Kymijoki watercourse 248 (Saarinen 1966, pp. 11-13), it can be calculated that the said amount of evaporation reduces the water mass discharging to about 50 percent of the present discharge. This evaluation is approximate since the decrease of evaporation from south to north has obviously been affected in our country also by factors other than mere change in temperature. This indicates, however, that a simple temperature rise by about two degrees is enough for the above - established reduction of the discharge amount, provided the amount of precipitation during the period in question was the same as now.

A higher temperature, however, also has its effect on the quantity of precipitation. According to Professor Palmén's verbal communication to me the larger absolute humidity contained in warmer air masses may increase precipitation. Unfortunately, we hardly have at present an adequate base to calculate mathematically how a certain temperature rise would affect the precipitation of Fennoscandia. Since climatic conditions during the period under consideration may have been approximately the same as nowadays during particularly warm years, I have indicated on diagrams for Jyväskylä (in the Päijänne discharge area) and for Kuopio (in the Saimaa discharge area) the precipitation for February, July and the whole year, with precipitation as the ordinate and temperature as the abscissa. As is shown by the diagrams (Figs. 5-10), dispersion is large, but nevertheless it can be ascertained that there is a rising tendency in the February precipitation as the temperature increases, whereas the July precipitation on an average falls slightly in warm summers. This corresponds to the generally known fact that summers with high precipitation, when cyclone activity is prominent, are generally cool (e.g. Keränen and Korhonen 1951, p. 112) and, again, that cloudy conditions in winter reduce re-radiation and thus moderate the cold. In the diagrams presenting the whole year precipitation rises slightly as the average temperature for the year increases. The correlation coefficient between average temperature and precipitation in February is for Jyväskylä +0.31 , for Kuopio +0.42 , in July for Jyväskylä -0.25 , for Kuopio -0.33 and in whole year for Jyväskylä +0.19 and for Kuopio +0.18 . Thus the correlation is in all cases weak. For the whole year it is not statistically significant even at the $5 \%$ probability level, however, the trend is suggested. So, the possible rise of precipitation due to higher temperature does not seem to have here had a noteworth effect upon the humidity. According to this it appears that even in the Atlantic period precipitation in the Lake Plateau was not much higher than it is now.

A local factor which could have influenced precipitation conditions is land uplift. The north-west end of the ancient Päijänne area was, at its isolation from the Baltic, $123 \mathrm{~m}$ lower than at present and after the Hinkua River had ceased activity the area was still an ample $80 \mathrm{~m}$ lower than now. The corresponding figures for the southern end of the watercourse were about $40 \mathrm{~m}$ and about $30 \mathrm{~m}$. The area was therefore very low-lying, which has served to reduce precipitation. It could, for this reason, have been even lower than at present. The greater size of the Gulf of Bothnia, on the other hand, has increased precipitation, so the significance 


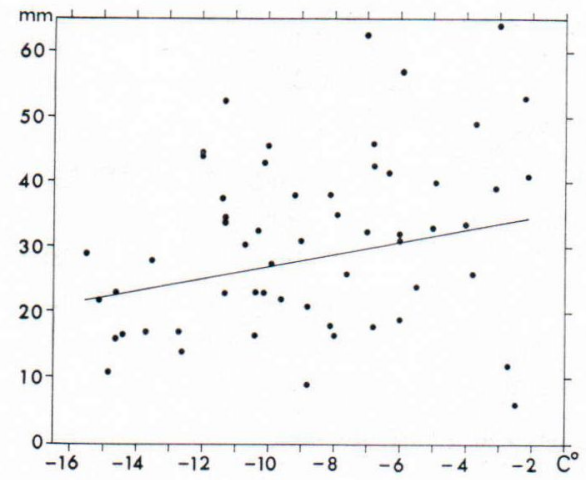

FIG. 5. Correlation between average temperature (abscissa) and precipitation (ordinate) for February at Jyväskylä since 1904 .

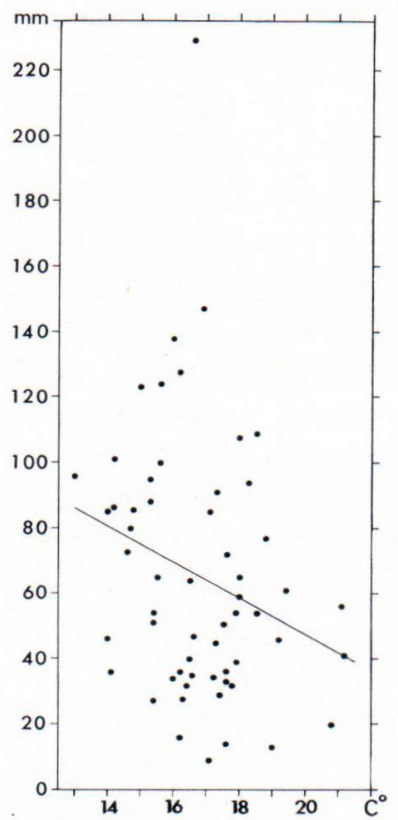

FIG. 7. Correlation between average temperature (abscissa) and precipitation (ordinate) for July at Jyväskylä since 1904.

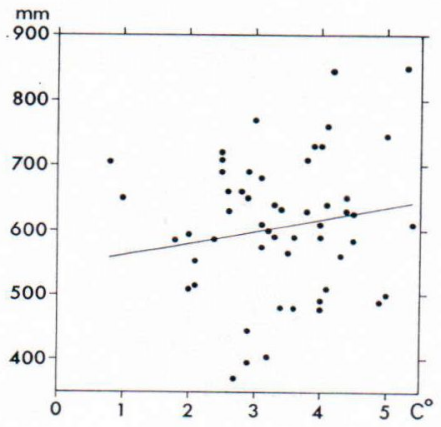

FIG. 9. Correlation between average annual temperature (abscissa) and precipitation (ordinate) at Jyväskylä since 1904.

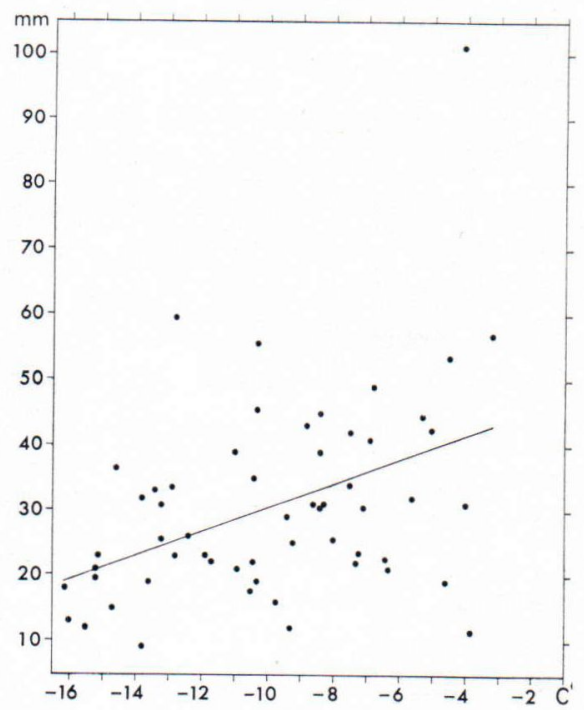

FIG. 6. Correlation between average temperature (abscissa) and precipitation (ordinate) for February at Kuopio since 1904.

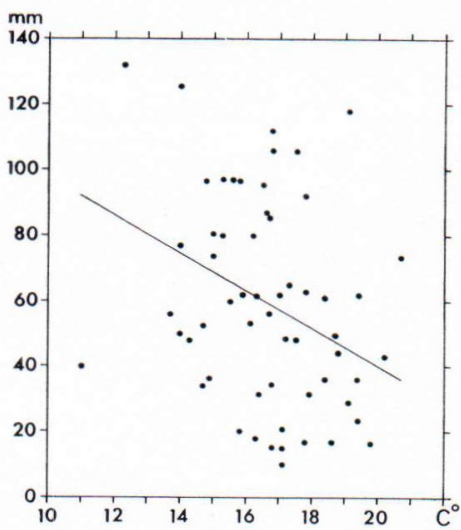

FIG. 8. Correlation between average temperature (abscissa) and precipitation (ordinate) for July at Kuopio since 1904.

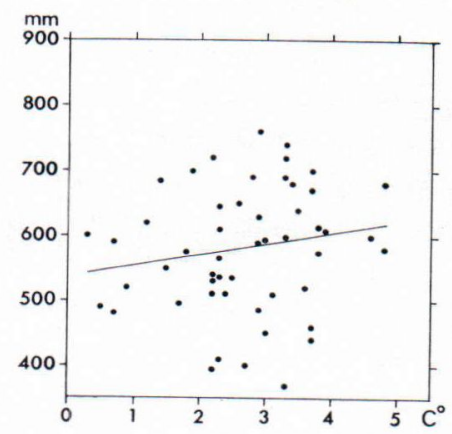

FIG. 10. Correlation between average annual temperature (abscissa) and precipitation (ordinate) at Kuopio since 1904. 
of this factor, which can only be estimated with difficulty, has hardly been very great.

As presented above, the dryness of the Atlantic period in South Finland, established with the aid of the Hinkua River discharge, was a direct consequence of the greater evaporation caused by higher temperature. By measurement of the discharge it has been possible to affirm that during the said period the mean run-off was at its maximum about $70 \%$ of the present, and it has also been established above that a two degree rise in temperature would be sufficient to decrease the discharge to about $50 \%$ of the present value. The difference is principally composed on the following three factors.

1) Precipitation may have been slightly larger than at present.

2) The run-off estimate for the Atlantic period, $70 \%$ of what it is now, is the maximum value. If, for the basis of the hydraulic calculations, a water height of $122.8 \mathrm{~m}$ were taken (R. Aario 1965 a) instead of the round figure of $123 \mathrm{~m}$, a lower value would have been reached. I considered it better, however, to take as a basis for calculations the value above which the mean high water level certainly did not rise.

3) The quantity of evaporation was calculated on a 2-degree rise in temperature. If, instead, the value of $1 \frac{1}{2}$ degrees had been used (p. 10), a discharge amount $67 \%$ of the present would be obtained.

When these three factors, effecting to the calculated values, are brought under consideration, we can see that the run-off amount measured by the Hinkua River discharge well corresponds to that value which we obtain by calculation using as a basis the increase in evaporation with temperature rise.
It is for this reason apparent that by changes of South Finland's climate there is also after the Atlantic period a positive correlation between a higher temperature and dryness. In the Lateglacial period and early Post-glacial period, when remnants of the continental ice still affected our country's climate, the case could have been otherwise. In Lapland - especially on the coast of the Arctic Ocean - which is in a different position in relation to wind zones than South Finland is, the development of humidity seems in some respects also to have taken on a different aspect than in South Finland (L. Aario 1943, 1952 b).

Independently of wind conditions, the lowering of annual mean temperature below a certain limit can also cause slightly warmer phases to become more humid than the colder phases. Precipitation in the winter season mainly takes places when the temperature is relatively close to zero, whereas bright, frosty weather does not bring rain. In addition, evaporation is insignificant below zero. If the summers are short and cool, and evaporation also small during that season, the colder periods may on an average turn out to be more dry than the slightly warmer periods.

Acknowledgements - Prof. V. Castrén, Professor of Hydraulics at the Institute of Technology, performed the hydraulic calculations. With academician, Prof. Dr. E. Palmén I have had valuable discussions and he has also kindly read the part of the manuscript that is concerned with climate. The calculations necessary for the statistical analyses were completed in the Computer Center of Oulu University. Mr. Matti Walldén assisted me in the field. The English translation of the manuscript was done by Mr. P. Jupp and checked by Prof. Dr. L. Lundgren. Sohlberg Foundation has given financial aid for my research project. To all the persons and institutes mentioned the author wishes to extend sincere thanks. 


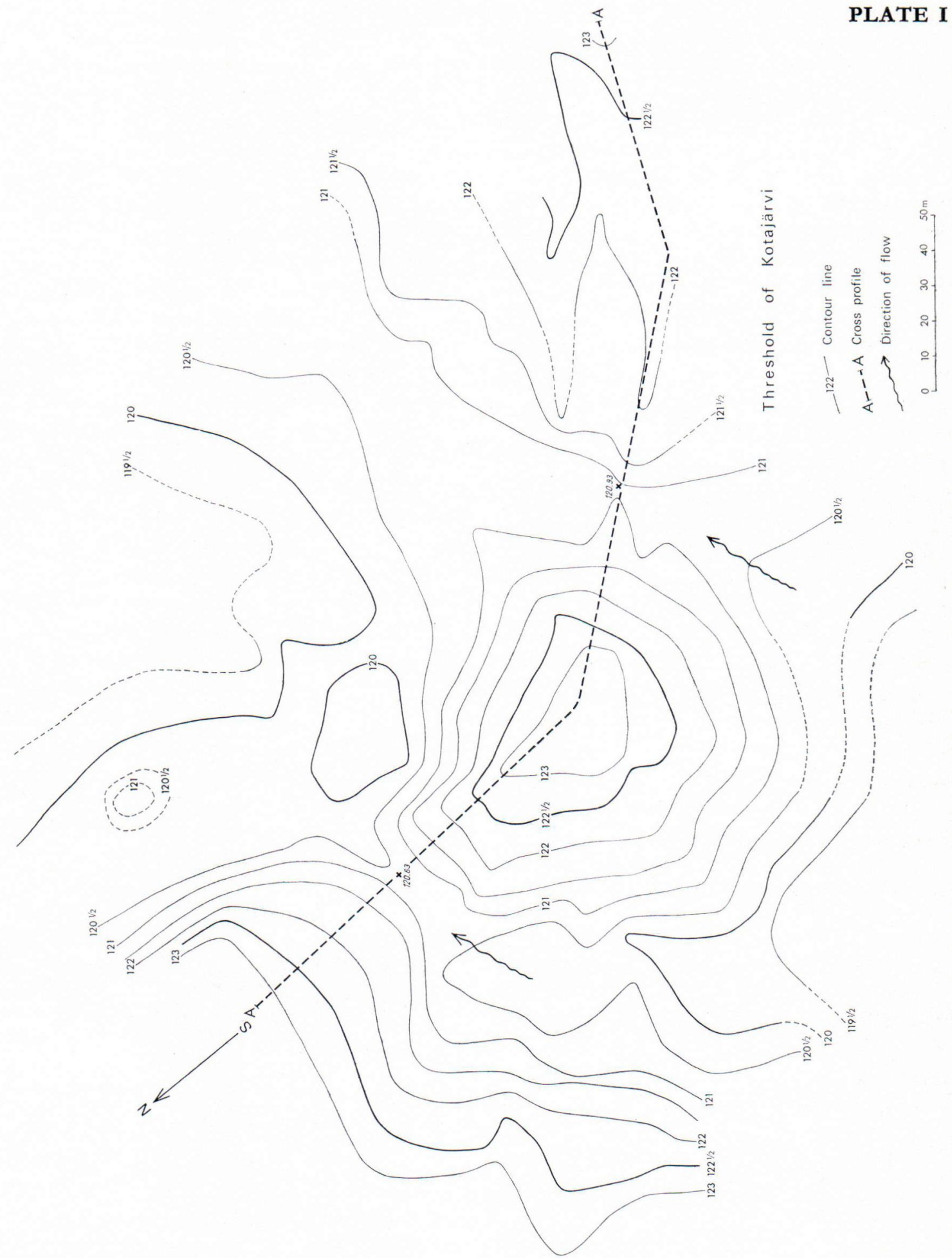

Plate I. Kotajärvi threshold area. 
PLATE II

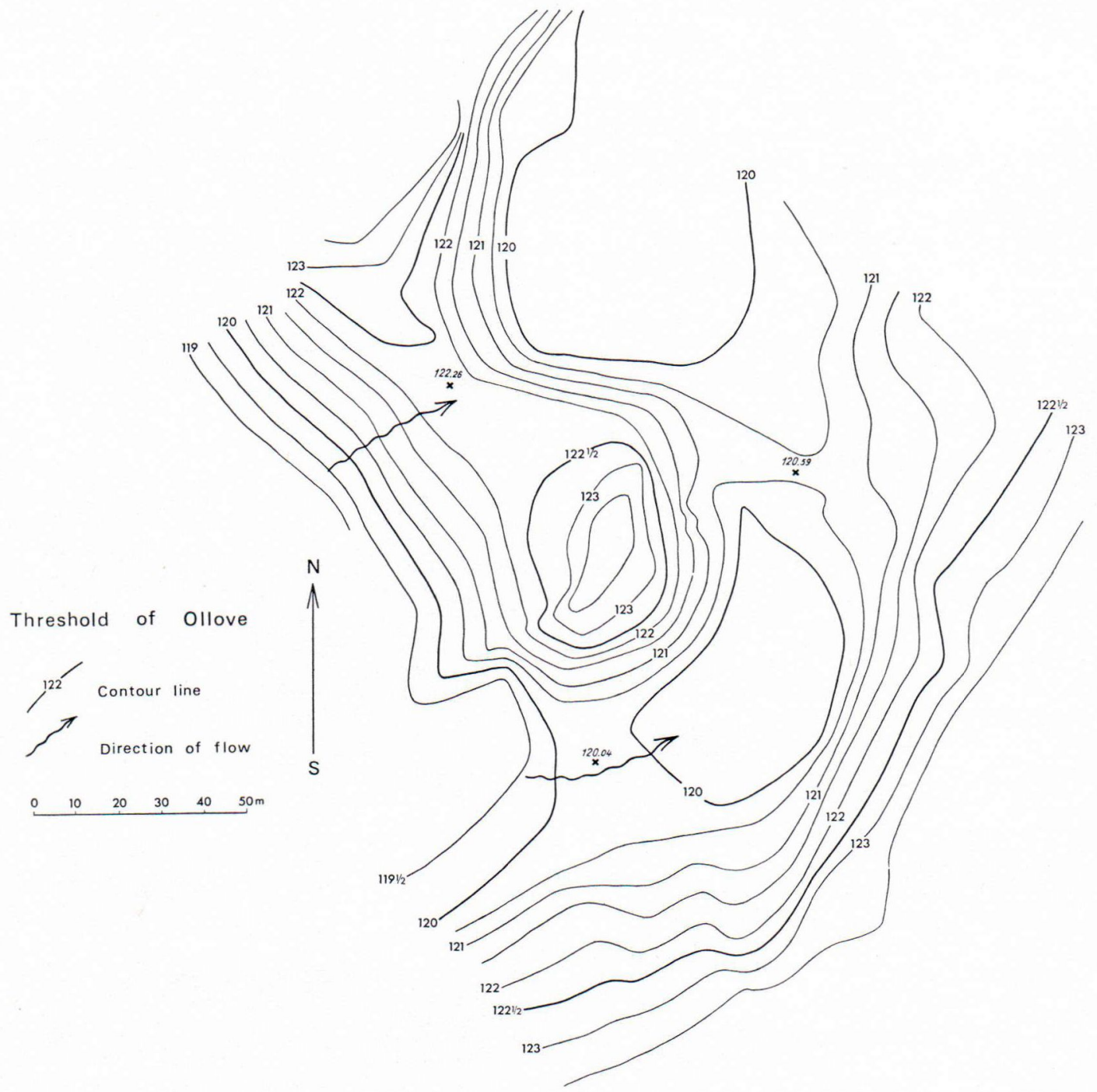

Plate II. Ollove threshold area. 


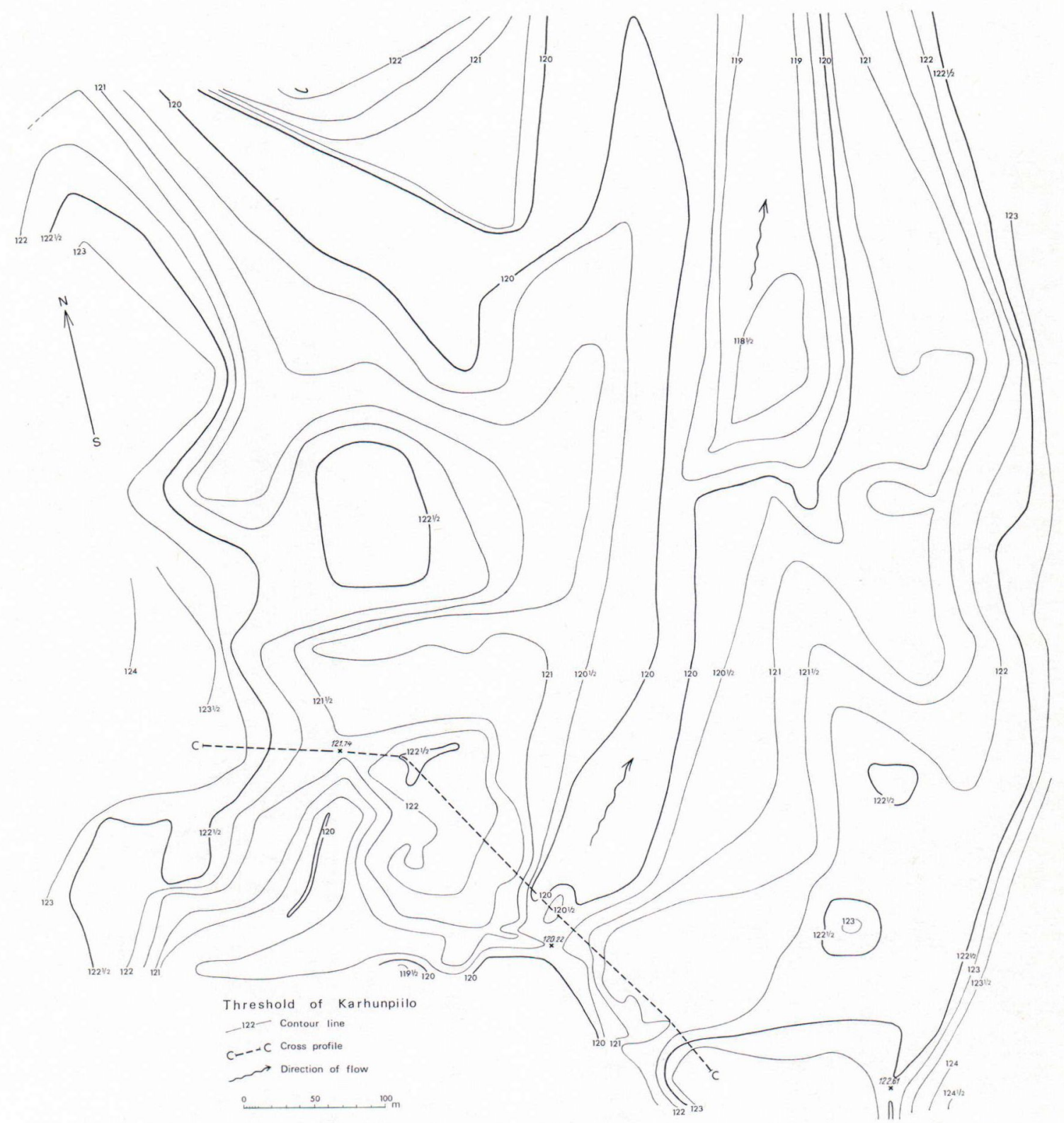

Plate III. Karhunpiilo threshold area. 


\section{REFERENCES}

Aario, Leo (1936) Entwicklung des südlichen VorPäijännesees. Fennia 62, 1.

- (1943) Über die Wald- und Klimaentwicklung an der lappländischen Eismeerküste in Petsamo. Ann. Bot. Soc. Vanamo 19, 1.

- (1944) Piirteitä jääkauden jälkeisestä ilmaston kehityksestä ja sen vaikutuksesta kulttuurihistoriaan. Terra 56.

- (1952 a) Über den südlichen Abfluss des VorPäijännesees. Public. Inst. Geogr. Univ. Turkuensis 24.

- (1952 b) Climatic changes and cultural geographic development. Proc. 8th Gen. Ass. - 17th Congr. Intern. Geogr. Union, Washington, 1952.

AArio, Risto (1965 a) Development of ancient Lake Päijänne and the history of the surrounding forests. Ann. Acad. Sci. Fennicae A 81.

- (1965 b) Die Fichtenverhäufigung im Lichte von $\mathrm{C}^{14}$-Bestimmungen und die Altersverhältnisse der finnischen Pollenzonen. Bull. Comm. géol. Finlande 218.

- (1966) Muinaisen Hinkuanvirran virtaama. Terra 78.

Aartolahtr, Torve (1966) Über die Einwanderung und die Verhäufigung der Fichte in Finnland. Ann. Bot. Fennici 3.

Andersson, Gunnar (1902) Hasseln i Sverige fordom och nu. Sveriges geol. unders. C, 3.

Averdieck, Fritz-Rudolf (1957) Zur Geschichte der Moore und Wälder Holsteins. Nova Acta Leopoldina 130, 19.

BERGLUND, BJörn (1966) Late-Quaternary vegetation in eastern Blekinge South-eastern Sweden. Opera Botanica 12, 2.

Borgässer, Elisabeth (1941) Das »Grosse Moor» bei Deimern, ein Hochmoor in der Lüneburger Heide. Beih. Bot. Centralbl. 61, B.

Granlund, ERIK (1932) De svenska högmossarnas geologi. Sveriges geol. unders. C, 373, Årsbok 26.

Gross, Hugo (1933) Zur Frage des Weberschen Grenzhorizontes in den östlichen Gebieten der ombrogenen Moorregion. Beih. Bot. Centralbl. 51, 2.

Hellaakoski, Aaro (1922) Suursaimaa. Fennia 43, 4.

- (1928) Puulan järviryhmän kehityshistoria. Fennia 51,2 .

- (1936) Das Alter des Vuoksi. Bull. Comm. géol. Finlande 115.

Iversen, Johs. (1944) Viscum, Hedera and Ilex as climate indicators. Geol. Fören. förhandl. 66, 3.

Jør Gensen, Svend (1963) Early Postglazial in Aamosen. Vol. 1. Danmarks geol. unders. 87.
Keränen, J. and Korhonen, V. V. (1951) Ilmasto, Suomen maantieteen käsikirja. Helsinki.

King, Guchlaine (1959) Beaches and Coasts. London. Kоцккт, Osmo (1960) Mean annual temperature, Atlas of Finland p. 5, map 1.

Lamb, H. H. (1966) The Changing Climate. London. Lappalainen, Veikko (1962) The shore-line displacement on southern Lake Saimaa. Acta Bot. Fennica 64.

LuNDQvist, Gösta (1962) Geological radiocarbon datings from the Stockholm station. Sveriges geol. unders. C, 589 .

Nilsson, TAge (1964 a) Standardpollendiagramme und $\mathrm{C}^{14}$-Datierungen aus dem Ageröds Mosse im Mittleren Schonen. Lunds. Univ. Årskrift, N. F. Avd. 2 Bd. 59, 7. Kungl. fysiogr. sällsk. handl. N. F. 74, 7.

- (1964 b) Entwicklungsgeschichtliche Studien im Ageröds Mosse, Schonen. Lunds Univ. Årskrift, N. F. Avd. 2 Bd. 59, 8. Kungl. fysiogr. sällsk. handl. N. F. 74,8 .

Nussbaum, Fritz (1934) Das Wasser des Festlandes. Klute: Handbuch der Geogr. Wissenschaft 1, 6. Potsdam.

Окко, Vегкко (1948) On the development of the Heposuo bog near the town of Kuopio. Bull. Comm. géol. Finlande 142.

- (1965) Kallaveden suurtulvasta. Savotar 5.

Overbeck, F. and Schneider, S. (1938) Mooruntersuchungen bei Lüneburg und bei Bremen und die Reliktnatur von Betula nana L. in Nordwestdeutschland. Zschr. Botanik 33.

- (1940) Torfzersetzung und Grenzhorizont, ein Beitrag zur Frage der Hochmoorentwicklung in Niedersachsen. Angew. Bot. 22.

RAMSAY, WILHELM (1926) Nivåförändringar och stenåldersbosättning i det baltiska området. Fennia 47, 4 .

SAARINEN, JAAKKo (1966) Virtaaman ja sademäärän keskiarvoja ajanjaksolta $1931-1960$ sekä virtaamanmittauksia vuosilta 1961-1965. Comm. Hydr. Off. 26.

Sauramo, Matti (1940) Suomen luonnon kehitys jääkaudesta nykyaikaan. Porvoo.

- (1958) Die Geschichte der Ostsee. Ann. Acad. Sci. Fennicae A 51.

Siмојокт, Hегккі (1966) Suomen vesitaloudesta. Summary: On the water budget of Finland. Soc. Sci. Fennica, Årsbok 44 B, 3.

Sirén, Allan (1960) Annual evaporation, Atlas of Finland p. 3, map 4.

Tolvanen, Viljo (1922) Der Alt-Päijänne. Fennia 43. VARJO, Uuno (1964) Über finnische Küsten und ihre Entstehung. Fennia 91, 2.

Manuscript received, April 19, 1968. 